\title{
No Democracy Without Comprehension: Political Unintelligibility as A Democratic Problem
}

\author{
Daniel Innerarity, University of the Basque Country, Ikerbasque \\ Foundation for Science, and European University Institute of Florence
}

Democracy is enly possible because of an increase in the complexity of society, but that same complexity seems to threaten democracy. There is a clear imbalance between people's actual competence and the expectation that citizens in a democratic society will be politically competent. It is not only that society has become more complex but that democratization itself increases the degree of social complexity. This unintelligibility can be overcome through the acquisition of some political competence-such as improving individual knowledge, diverse strategies for simplification or recourse to the experts-that partially reduce this imbalance. My hypothesis is that despite the attraction of de-democratizing procedures, the best solutions are those that are most democratic: strengthening the cooperation and the institutional organization of collective intelligence. The purpose of this article is not to solve all the problems I touch on, but rather to examine how they are related and to provide a general framework for the problem of de-democratization through misunderstanding.

Keywords: democracy, intelligibility, experts, complexity

An abundance of evidence suggests that we live in a democracy of incompetent people. We talk about a "monitory democracy" that has "power-scrutinizing mechanisms," but the truth is that our citizens lack the ability to scrutinize because of a shortage of political knowledge, or because of being overwhelmed, poorly informed, and incapable of processing the cacophony of information, or simply because of uninterest. Our political problems are caused by the fact that democracy needs more actors than it is incapable of producing. ${ }^{2}$

I would like to thank the two anonymous reviewers for their comments and suggestions.

1. John Keane, The Life and Death of Democracy (London: Simon and Schuster, 2009), 688.

2. Hubertus Buchstein, "Die Zumutungen der Demokratie: Von der normativen Theorie des Bürgers zur institutionell vermittelten Präferenzkompetenz," in Politische Theorien in der Ära der Transformation, ed. Klaus Beyme and Claus Offe (Opladen: VS Verlag für Sozialwissenschaften, 1996), 295-324, at 295.

Published online Month XX, 2021. https://doi.org/10.1086/713705

Polity, volume 53, number 2 (April 2021), pp. 000-000. 0032-3497/2021/5302-00XX\$10.00.

(C) 2021 Northeastern Political Science Association. All rights reserved. 
The critical observation of politics is increasingly difficult because of our inability to process information, the complexity of topics, and the contingency of decisions. The crisis in the financial system, the complexity of negotiations about climate change, the conditions for the sustainability of our pension systems, or the impact of automation of the workplace are issues that have led to feelings of rage or fear, but they are barely comprehensible for most people. There is no democracy without a public opinion that exercises effective control over power, formulates its criticisms, and asserts well-founded demands. Democrcacy presupposes that public opinion correctly understands the political processes. The problem is that this is not the reality in our democracies, and the growing complexity of politics makes it difficult for there to be a relevant public opinion when it comes to understanding and judging what is taking place, something that is in clear contradiction with one of democracy's basic normative assumptions. One of the central figures of the classic model of democracy is the-informed citizen who is capable of determining what he or she thinks about political matters and participating in the processes through which corresponding decisions are adopted. Even though this figure has always been exaggerated from the normative point of view, the new conditions of the world in which we live seem to have turned this figure into wishful thinking or an anachronism.

In the same way that the people and the social contract were founding myths, useful fictions - such as the idea of citizens who continuously monitor power-that explain and legitimize political power are not really available $\overline{\mathbf{i}}_{\mathbf{1}}$ The power of the public when it comes to formal politics has always been merel ffr tgmentary, passive, indirect, and imprecise. Understanding it in any other way is to give oneself over to frustration. "Modern society is not visible to anybody, nor intelligible continuously and as a whole."3 The unintelligibility of politics is a problem that can scarcely be resolved by optimizing the handling of information or the available technology. This unintelligibility is not merely a cognitive deficit, but a democratic one: if there is a profound imbalance between what a democracy assumes about its citizens and the citizens' ability to fulfill these demands, if people cannot make a reasonable choice, as was to be expected, then self-government is impossible. When citizens or voters are overwhelmed and are not able to comprehend what is at stake, then freedom of opinion and the freedom to make decisions can be considered a formal recognition that is unrealizable.

3. Walter Lippmann, The Phantom Public (New Brunswick, NJ: Transaction Publishers, 1993), 32. 
Public opinion that does not understand politics and is unable to judge it can be easily weaponized, or it may send equivocal signals to the political system. This confusion explains many of the most regressive political behaviors: populist simplification, the inclination toward authoritarian decisionism, or the passive consumption of a politics that is staged by the media. Politics becomes "organized dilettantism," to the extent that its operations only have value as entertainment, as is revealed, for example, by the fact that we discuss people more than political issues or the growing value of scandal in politics, which replaces the exchange of arguments.

\section{Political Unintelligibility}

From Aristotle to Rousseau, the idea of a well-governed society was conditional upon being of a size that made it visible and intelligible, where all the citizens should know one another and society would have the immediacy of a community. This idea of mutual knowledge continues almost all the way to the present: in the mid-nineteenth century, French historian Jules Michelet declared that the Republic could not be created if people did not know each other, which began a series of surveys and a media campaign throughout the country. In the US, after the 1929 crisis, President Roosevelt encouraged the reconstruction of society through mutual knowledge, an idea that was also reflected in literature (Steinbeck's The Grapes of Wrath) and photography from that time period. ${ }^{5}$ It was not a quantitative or physical measurement as much as one of intelligibility. The term "unintelligibility" somewhat translates the "Unübersichtlichkeit" of Habermas, ${ }^{6}$ which is a perfect expression of the fact that current societies no longer satisfy that criterion of closeness in any way, and they have to fulfill the conditions of democratic government within other more complex parameters. More than a quality of things, complexity consists of a relationship between the person who observes and that which is observed, describing an excessive demand on the observer, whose perceptiveness and comprehension become overwhelmed. As the complexity of the system expands, there is a corresponding

4. Burkhard Wehner, "Organisierter Dilettantismus oder demokratische Expertenkultur? Bürgerbeteiligung in der Endzeit des politischen Generalismus," in Politische Beteiligung und Bürgerengagement in Deutschland: Möglichkeiten und Grenzen, ed. Ansgar Klein and Rainer Schmalz-Bruns (Baden-Baden: Nomos, 1997), 252-76, at 259.

5. Pierre Rosanvallon, Refonder la démocratie pour le bien public (Toulouse: Privat, 2018), $45-48$.

6. Jürgen Habermas, Die neue Unübersichtlichkeit (Frankfurt: Suhrkamp, 1985). 
increase in the amount of time and cognitive resources that the observer needs to describe it adequately. ${ }^{7}$

From the point of view of social ontology, unintelligibility stems from the plurality of realities present in a society that cannot be turned back into a totalizing social unit without losing the richness associated with that plurality. As Dewey noted, politics includes many public spaces—rather than one simple, unified space-and they cross and overlap, making it very difficult for them to integrate into a singular and total public space. ${ }^{8}$ Schumpeter addressed the confusion of situations, contexts, influences, and actors in the democratic process. ${ }^{9}$ The functional differentiation of modern societies is not something that resolves problems but is, instead, "a generator of problems." 10

The principal problem is the loss of social visibility, the intelligibility of society. If there is a crisis of politics, it is precisely because it is unable to fulfill its function to make society - as well as its issues and discourses and the responsibility for actionsvisible; it fails to make society more intelligible. There is a function of politics that has to do with the visibility of society as a whole, a certain "representation of the whole, without being whole." ${ }^{\prime 1}$ And that is what politics has not been able to carry out as we had hoped.

One of the reasons for the opaqueness of politics is its entry into supranational realms that make it lose intelligibility; the areas of reference are blurred, and interdependence makes the lines of jurisdictions, merit, and responsibility unclear. Exogenous factors explain the good and bad things that happen to us better than the decisions themselves do. The nation state had, among other things, been a framework of intelligibility for politics, and its involvement with other global actors implies that the categories associated with it that organized our perception of politics are also weakened. But when there are many levels, interactions, changes of context, observation becomes more difficult. Politics becomes more complicated when

7. Nicholas Rescher, Complexity: A Philosophical Overview (Transaction Publishers: New Brunswick, N.J., 1998), 16.

8. John Dewey, The Public and its Problems (New York: Holt, 1927).

9. Joseph A. Schumpeter, Capitalism, Socialism, and Democracy (New York: Harper \& Brothers, 1942).

10. Armin Nassehi, Differenzierungsfolgen: Beiträge zur Soziologie der Moderne (Opladen: VS Verlag für Sozialwissenschaften, 1999), 23; Uwe Schimank, Die Entscheidungsgesellschaft. Komplexität und Rationalität der Moderne (Wiesbaden: VS Verlag für Sozialwissenschaften, 2005), 148.

11. Armin Nassehi, Die soziologische Diskurs der Moderne (Frankfurt: Suhrkamp, 2009), 336. 
the number of actors and systems increases, when interests diverge and when decision-making processes become harder to understand.

Many political issues are very difficult to translate in such a way that they are intelligible to anyone. Some topics are very heavy on information, some reference other topics and demand complicated decisions, and other topics have consequences that are difficult to fathom. Examples include the control of the transnational financial economy, the bewilderment provoked by new technologies, technological innovation or the media merry-go-round, processes of decision-making involving many actors, and the identification and management of risks.

Problems of intelligibility do not have as much to do with the objective difficulty of these topics as with their subjective difficulty. Their overwhelmingness is not only due to a lack of information, cognitive capabilities, or disinterest. The main reason they are excessive and that citizens find themselves overwhelmed when it comes to observing, understanding, and judging political events is the range of possible outcomes given the diversity of perspectives and the contingency of political decisions in a similar environment. The institutions that used to mediate (political parties, labor unions, and the traditional media) barely exercise this simplifying function. It is not only that the demos is overextended, but that the elites and experts are as well. How then can the function of public control be exercised? How can we address everything that is politically relevant to come up with a coherent and rational judgment about public affairs? In the face of these difficulties, one might conclude that it is wishful thinking to believe that human beings are capable of understanding the behavior of institutions and of society as a whole. ${ }^{12}$

The unintelligibility to which I am referring, which is relevant to the effects of the problem we are considering here, is not the complication of social realities (of subsystems, of technological infrastructures, or of comprehension of the functioning of interdependencies in a globalized world); neither is it exactly a lack of preparation on the part of the citizens. Society is full of black boxes, in other words, of artifacts whose usage value is not made more difficult by the fact that we do not understand their technical functioning. The unintelligibility that is politically relevant and that erodes democracy is the lack of comprehension of those aspects of political life that citizens need to know to exercise their functions of monitoring and control. Or, at a minimum, the unintelligibility that cannot be resolved through adequate delegation to bodies upon which confidence can be placed (parties,

12. Helmut Willke, Dystopia. Studien zur Krisis des Wissens in der modernen Gesellschaft (Frankfurt: Suhrkamp, 2002), 50. 
experts, and institutions), as long as that confidence is justifiable and susceptible to revision, not an abdication of their sovereignty.

\section{Democracy as a Complication}

Social systems can try to reduce complexity by eliminating it, ignoring it or fighting it, but they can also permit or even encourage it. This last aspect is very important for democracy, which can be understood precisely as the set of rules that allows us to articulate a greater complexity, is open to questioning of any kind, encourages controversy, increases the number of interlocutors, does not reject criticism on principle, and allows the configuration of alternatives. By its very nature, democracy is a generator of contingency; politicizing or democratizing implies complicating certain things that were previously decided by tradition, questioning the established authority, expanding the field of the politically debatable-in sum, multiplying possibilities.

In a democratic society, public opinion or social movements tend to politicize more and more topics. In other words, they remove them from their own opacity or their unquestioned nature and turn them into objects of a collective free decision. This demand increases the contingency of the political both from a quantitative and a qualitative point of view: there are an ever-expanding number of issues that are subject to public discussion and about which a public decision is demanded. This "proliferation of new concerns"13 is the principal cause of an expansion of the political that tends to include new issues in the political agenda such as, for example, those referring to the body or health.

This increase in topics and opinions implies questioning the lines of demarcation that separate responsibilities, delimiting what is pertinent and protecting the zones of power. This extension of what is political takes places in the face of tradition as destiny, the structures of power, hegemonic discourses, and monopolies of interpretation. Public opinion promotes reflection about that which is implicit, revealing and inciting criticism. Durkheim defined democracy as the political form of reflection. ${ }^{14}$ The very vitality of a democracy (where there are many forces interested in protecting power) moves issues that were originally considered non-political toward the space of the political. Many areas that were previously handled by the state or by those in the fields of science and technology have opened up to democratic

13. Samuel Popkin, The Reasoning Voter: Communication and Persuasion in Presidential Campaigns (Chicago: University of Chicago Press, 1991), 36.

14. Émile Durkheim, Leçons de sociologie, (Paris: PUF, 2015). 
discussion. Politics is about alternatives, options, interpretations, and perspectives. All positions, convictions, goals and decisions are subject to a provisionality of principles and the possibility of revision. This revisability can be institutionalized (through parliamentary opposition, for example), or it can be exercised from outside institutions. In any case, it implies that the political system has renounced a privileged relationship with the truth. ${ }^{15}$ Within a democracy, there is no final truce for the production of possibilities and alternatives. There are no emphatic indicators that can confirm any particular policy, for example; any indicator can be brought down with the emergence of new assessment criteria.

Democracy has to do with the contingency of things, which could always be different. Being conscious of this contingency allows us to see political circumstances as the product of historical processes and not as destiny; they are the results of human action, configurable, and changeable. That is why there is no political life without coexistence, competition, or conflict. Tocqueville spoke of the "permanent anxiety" of democracy ${ }^{16}$ and Luhmann about a "continuous irritation." 17 This circumstance is what explains democracy's openness, its indetermination, and discontinuity. "Democracy is a system of ruled open-endedness, or organized uncertainty." 18

\section{The Acquisition of Political Competence}

The new majority today is constituted by those who do not understand. As Durkheim noted, ${ }^{19}$ our representatives' lack of competence tends to be a reflection of a similar lack of competence in the citizens. The normative theory of democracy does not seem very realistic, whether we take the assumption of a generalized lack of competence as our starting point or whether we presume an insurmountable asymmetry when it comes to political capabilities. ${ }^{20}$ Is it possible to acquire the ability that allows citizens to exercise the functions that are expected from them in a democracy?

15. Hans Kelsen, Vom Wesen und Wert der Demokratie, (Tübingen: Mohr, 1920), 102.

16. Alexis de Tocqueville, De la démocratie en Amérique, II, 3, ed. Michael Lévy (Paris: Libraires éditeurs, 1835), 219.

17. Niklas Luhmann, Soziologische Aufklärung 4, Beiträge zur funktionalen Differenzierung der Gesellschaft (Opladen: VS Verlag für Sozialwissenschaften, 1987), 129.

18. Adam Przeworsky, Democracy and the Market: Political and Economic Reforms in Eastern Europe and Latin America (London: Cambridge University Press, 1991), 13.

19. Émile Durkheim, Leçons de sociologie (Paris: PUF, 2015).

20. Sven-Uwe Schneider, Homo democraticus: Demokratische Tugenden in der Ideengeschichte (Opladen: VS Verlag für Sozialwissenschaften, 200), 261. 
Participation in the political system requires an ever-greater degree of capability. Taking as my starting point the idea that it is not very clear what kind of competence is required to understand and participate in politics. I propose grouping together the possible solutions involving the training of individual judgment, strategies for simplification, and the recourse to experts, before tackling the more democratic solutions that require the strengthening of collective intelligence.

What must one know in a democracy? The nexus between formal education and political competence is not obvious. What type of education is necessary for what type of politics? How do we make compatible the need to make citizens more politically competent with the principle that there is universal competence when it comes to politics in a democracy? Democracy was made for the people, not the other way around. Who is right, the elitist Mill or the populist Rousseau? How do we determine what the average citizen should know about public affairs?

Democracy presupposes an accessible and shared knowledge that one should have to participate in public deliberation and decision-making. Of course, we citizens cannot and should not be experts, but "generalists," ${ }^{21}$ but there is a threshold below which we would be incapable of carrying out thoughtful civic judgment. ${ }^{22}$ It is a question of having a general overview about politics; we cannot be expected to have much more than that, especially if we keep in mind the lack of time, the finiteness of our attention span, uncertain knowledge, or the complexity of issues. But I would like to insist that political competence is not so much knowledge about the content of politics but about the logic of politics. There are those who do not understand its logic even though they accumulate a great deal of knowledge about its content. Political education is not so much the accumulation of information as the awareness of the complex and contingent nature of politics. The main thing that must be learned is that political knowledge is an opinion and not apodictic knowledge; that it is made up not only of verifiable fact but also the interpretations, perceptions, and convictions of different social groups, a plurality of narratives, traditions, and visions of the world. Political competence is an ability to confront that diversity of opinions and interests, and come up with a coherent image of reality.

21. Michael Delli Carpini and Scott Keeter, What Americans Know About Politics and Why It Matters (New Haven: Yale University Press, 1996), 151.

22. William Galston, "Political Knowledge, Political Engagement, and Civic Education," Annual Review of Political Science 4 (2001): 217-34, at 218. 
Competence has a meaning that goes beyond the cognitive. Münkler refers to an ability to discern the collective social horizon in such a way that not only are one's own interests kept in mind, but also the possibility of limiting or renouncing them. ${ }^{23}$ Part of this ability stems from the capacity to address political conflicts through dialogue, the ability for compromise, a certain openness to being disappointed or the sensitivity to perceive situations that disadvantage or exclude others. We might also include a certain irony, in Rorty's sense, ${ }^{24}$ regarding one's own opinions, being aware of their idiosyncratic and contingent nature and the possibility they will be revised. The ideal of thought that is free and without prejudice would be one "that favors the person who seeks novel information and experience, is open to full and honest communication, who can tolerate various kinds of uncertainty and even ignorance in the short run in order to gain knowledge, and who is not defensive about prior beliefs." 25

Political education is not only a cognitive ability but one that implies other aptitudes of an emotional nature. Education opens access to topics but also implies a general interest in them, a motivation, awareness of oneself as a citizen, and a critical attitude when it comes to manipulation. Knowledge and education also have a motivational effect; they not only improve our cognitive resources for politics but also the interest in expressing our opinion and participating. This could just as easily be said in the inverse: emotions are not only feelings but have a cognitive value; they also serve to categorize the world and reduce the complexity of the political. ${ }^{26}$ This could also be formulated with a logic of political "economy": "affective information can substitute for more cognitively expensive forms of information." ${ }^{27} \mathrm{~A}$ capacity for emotional identification with certain political problems-sensitivity when it comes to taking care of the environment or empathy about injustice, for

23. Herfried Münkler, "The kompetente Bürger," in Politische Beteiligung und Bürgerengagement in Deutschland: Möglichkeiten und Grenzen, ed. Ansgar Klein and Rainer SchmalzBruns (Baden-Baden: Nomos, 1997): 153-72, at 157.

24. Richard Rorty, Contingency, Irony, and Solidarity (London: Cambridge University Press, 1989).

25. Michael Smithson, Ignorance and Uncertainty. Emerging Paradigms, (New York: Springer, 1988), 152.

26. Martha Nussbaum, Political Emotions: Why Love Matters for Justice (Cambridge: Harvard University Press, 2013), 18.

27. Wendy Rahn, "Affect as Information: The Role of Public Mood in Political Reasoning," in Elements of Reason. Cognition, Choice, and the Bounds of Rationality, ed. Arthur Lupia, Mathew McCubbins and Samuel Popkin, (London: Cambridge University Press, 2000): 13050 , at 139 . 
example-saves us from needing extensive information. In some way, thanks to our emotions, we already know the most important things we need to know.

In any case, even though specific education improves political knowledge, it is best not to expect too much out of it and to take into consideration its possible negative effects. Some studies reveal that an increase in education does not improve citizens' understanding of politics. ${ }^{28}$ If the democratization of issues has as an effect an increase in uncertainty, not even those with the most education fulfill the expectations of resolving uncertainty through knowledge. It is enough to mention the innumerable errors of experts, who have enormous advantages when it comes to confronting complexity but who are not immune from mistakes. Knowledge and education are not a guarantee that the decisions we make will be correct.

It is important not to lose sight of the fact that education and expert knowledge have their own risks, precisely those that stem from their own certainty. At times, having a lot of knowledge makes one more inclined to certain specialist risks, like the inability to see the big picture, or overconfidence. ${ }^{29}$ The comprehension of politics does not necessarily depend on one's social group or amount of education. Political indifference is also found among those who have the most education. ${ }^{30}$ There is even a perverse equivalency between knowledge and sectarianism that should unsettle us. "The minority of citizens who are highly attentive to public affairs are scarcely more critical: they respond to new issues mainly on the basis of the partisanship and ideology of the elite sources of the message." 31

Given the complexity and conditions of the current world, we all have the experience of being inexperienced in practice and we find, in the end, that we make decisions without sufficient preparation. "The problem is not that mass publics know too little, but that no one knows enough." ${ }^{2}$

28. Eric Smith, The Unchanging American Voter (Berkeley: University of California Press, 1989), 219.

29. Richard Petty and John Cacioppo, Communication and Persuasion. Central and Peripheral Routes to Attitude Change (New York: Springer, 1986), 78; and Elisabeth Wehling, Politisches Framing: Wie eine Nation sich das Denken einredet-und daraus Politik macht (Köln: Halem, 2016), 51.

30. Hans Mathias Keplinger, Die Demontage der Politik in der Informationsgesellschaft, (Freiburg: Alber, 1998), 29.

31. John Zaller, "Floating Voters in U. S. Presidential Elections, 1948-2000," in Studies in Public Opinion: Attitudes, Nonattitudes, Measurement Error, and Change, ed. Willem Saris and Paul Sniderman (Princeton: Princeton University Press, 1992): 166-212, at 211.

32. Paul Sniderman, Richard Brody and Philip Tetlock, Reasoning and Choice: Explorations in Political Psychology (Cambridge University Press, 1991), 71. 
Information and Political Knowledge Complexity is asymmetrical when it comes to information, which leaves us with very little information or too much. The unintelligibility I am describing has a lot to do with the complexity produced by information itself, because of its excessiveness. Quantitative complexity is combatted selectively and qualitatively, relying on knowledge.

Democracy begins with the idea that the informed citizen participates rationally in political life and is capable of providing judgments and making contributions to political processes, from simple electoral participation to explicit political commitment. We have generally thought that this capacity required a certain amount of information, and we have given very little attention to the possibility that what was preventing the fulfillment of that political life was actually an excess of information. We can say without exaggeration that the "fully informed democracy" described by Downs, ${ }^{33}$ rather than a desirable objective, is a true threat. The more information released, the more unintelligible the world feels to us. The production of information, which is an assumption of democracy, blocks democracy when it becomes overwhelming.

What we have today is a proliferation of data and information, political spam, omnipresent publicity, demands for our attention, multiple opinions, communication in every direction, noise. Ordinary citizens now live politics as excessive noise that does not help them orient themselves but manages to irritate them, which Gehlen $^{34}$ labeled as over-excitement, a type of global warming of the citizenry. The mere quantity of facts and opinions is very difficult to process. Beyond a certain threshold, the increase in information does not contribute to knowledge; it simply becomes unintelligible. "Profusion breeds confusion." ${ }^{35}$ A general overview of things is not possible, and thus we confront phenomena such as disorientation or a loss of the sense of reality.

We could begin by confirming in this regard a peculiar economy of information. "Political information is to politics what money is to economics: it is the currency of citizenship." ${ }^{36}$ This currency seems to be exposed to a type of inflation that devalues the circulating information and thus complicates the comprehension of

33. Anthony Downs, An Economic Theory of Democracy (New York: Harper \& Bros, 1957).

34. Arnold Gehlen, Der Mensch. Seine Natur und seine Stellung in der Welt (Wiesbaden: Athenaion, 1978), 36.

35. John Keane, The Life and Death of Democracy (London: Simon and Schuster, 2009), 746.

36. Michael Delli Carpini and Scott Keeter, What Americans Know About Politics and Why It Matters (New Haven: Yale University Press, 1996), 8. 
politics. ${ }^{37}$ Berardi talks about a "semio-inflation,"38 and Postmann claims that the containment dikes have been broken by the flood of information and our immune system has stopped working in the face of that information. ${ }^{39}$ Schelsky ${ }^{40}$ warned years ago about the danger of de-politicizing and de-democratizing the citizen through an excess of information, and Morozov $^{41}$ is currently expressing concern about whether the concept of democracy we have now has only worked at a time when information was minimal.

The economy of information corresponds to a certain economy of attention, keeping in mind the current conditions of political observation: a lack of time and attention, an acceleration of processes, informational overload, the unusualness of the issues, uncertainty of knowledge. Information circulates in a rather disorganized fashion; on the internet there is outdated and even false information, but also things that are more banal that act to interrupt information or focus attention on irrelevant details. The aggressivity with which our attention is demanded has the counterproductive effect of continuous interruptions, a lack of concentration and saturation that ends up provoking disinterest. The continuous change of topics, their rapid devaluation, impedes the reflexive organization of new information in an all-encompassing and coherent image of the political. It is very difficult to maintain a general, balanced vision of it all, a true political memory, in a way that can provide order and coherence to this nonsensical succession of facts and opinions that exercises power over our attention span and does not necessarily correspond with its true informational value. We are too slow for politics; the acceleration of processes is as unable to resolve this problem as actors' agitation.

Society's informational infrastructures - the weakness of the old ones and the nature of new ones-help very little when it comes to facilitating the task of fighting against informational excess. If we begin with traditional media, the first thing we realize is that they have lost their function as gate keepers and have to a large extent been replaced by search engines, news aggregators, and algorithms. That task of filtering, better or worse carried out by the classic media, implied the introduction of

37. Richard Münch, Dynamik der Kommunikationsgesellschaft (Frankfurt: Suhrkamp, 1995), 36.

38. Franco Berardi, Der Aufstand: Über Poesie und Finanzwitschaft (Berlin: Matthes \& Seitz, 2012), 41.

39. Neil Postmann, "Wir informieren uns zu Tode", in Die Zeit 41 (2.10.1992), 62.

40. Helmut Schelsky, Der Mensch in der wissenschaftlichen Zivilisation (Opladen: VS Verlag für Sozialwissenschaften, 1961), 459.

41. Evgeny Morozov, The Net Delusion: The Dark Side of Internet Freedom (New York: Public Affairs, 2011), 75. 
criteria of relevance, which also leads to a reduction of complexity, and its crisis is equivalent to the crisis of our capacity to digest the explosion of information. It is true that the development of new informational and communication technologies has a democratizing effect to the extent that they allow continuous public observation, question marginalization and exclusion, and increase the accessibility of knowledge. But on the other hand, they exacerbate the desperation of those who are excessively informed, ${ }^{42}$ the "disinformed information society." 43 Today it is the search engines and algorithms that decide what we should know, but behind these technologies, there are commercial criteria and private interests that do not end up constructing a trustworthy and reliable space.

The struggle against excessive information has a quantitative and a qualitative side. The quantitative reduction of complexity has to do with the sufficient management of attentiveness, or more accurately, of inattentiveness. The failure to pay attention to everything, the interruption of deliberations, and economizing of information, has the curious effect of improving our political empowerment, to the extent that only in this way are we capable of managing the proliferation of information. Here we would have an actual limit to the deliberative theories of democracy, that by their very nature point toward an unlimited horizon of communication and do not foresee a justification to carry out an interruption of the processes at any time. Habermas himself recognized the existing "cognitive overload" in deliberative democracy, ${ }^{44}$ which is not very complex when it comes to elaborating available knowledge. Those who make decisions based on more information are not necessarily those who make the best decisions. ${ }^{45}$ In addition, some authors claim that, under certain conditions, having little information leads to better decisions. ${ }^{46}$ There is an "economy of becoming informed," ${ }^{47}$ that makes it very reasonable to deal with data selectively or, we could say, superficially, a type of "cognitive stinginess." 48 "We cannot afford to attend to information simply because it is

42. Niklas Luhmann, Soziologische Aufklärung 5, Beiträge zur funktionalen Differenzierung der Gesellschaft (Opladen: VS Verlag für Sozialwissenschaften, 1995), 80.

43. Scott Lash, Critique of Information (London: Thousand Oaks, 2002), 76.

44. Jürgen Habermas, Faktizität und Geltung. Beiträge zur Diskurtheorie des Rechts und demokratischen Rechtstaats (Frankfurt: Suhrkamp, 1992), 389.

45. Daniel Kahneman, "Maps of Bounded Rationality: Psychology for Behavioral Economics." American Economic Review, December 2003: 1449-75, at 1469.

46. Gerd Gigerenzer and Daniel Goldstein, "Reasoning the Fast and the Frugal Way: Models of Bounded Rationality," Psycological Review 103/4 (1996): 650-69, at 652.

47. Anthony Downs, An Economic Theory of Democracy (New York: Harper \& Bros, 1957).

48. Werner Wirth and Jörg Matthes, "Eine wundervolle Utopie? Möglichkeiten und Grenzen einer normativen Theorie der (medienbezogenen) Partizipation im Lichte der neueren Forschung 
there." ${ }^{49}$ It is possible to be only "moderately" rational, exercising an incomplete "bounded" rationality, which does not mean renouncing rationality as such. "If rationality were only possible in the light of complete information, it would perforce become totally irrelevant for us." ${ }^{\prime 50}$ Handling attention adequately requires dominating "the difficult art of rejecting information," ${ }^{11}$ cultivating "selective ignorance," 52 and practicing the art of intentional forgetting. ${ }^{53}$ "Competence requires very little information" 54 or, if you prefer to formulate it like this, a "low-information rationality, ${ }^{\prime 5}$ which would be at the core of the voter who, as Sartori maintains, is a simplifier and should continue to be one, since he or she must confront the complexity and contingency of the political. ${ }^{56}$

But our great challenge is the qualitative reduction of complexity, the transformation of data into information and knowledge. The production of information is an additive process, not a narrative one; it neither instructs nor guides. Without an interpretative elaboration, information stops being relevant when it comes to resolving problems and guiding action. The profusion of rankings, benchmarks, and metrics of social factors corresponds to this necessity; those measures only satisfy in a quantitative sense, as they are an insufficient response to the search for political meaning of what we are measuring. This inability to articulate meaningfully may be what leads to our difficulties when it comes to distinguishing between what is important and what is not-the large collective distractions where political life often

zum Entscheidungs- und Informationshandeln," in Demokratie in der Mediengesellschaft, ed. Kurt Imhof, Roger Blum, Heinz Bonfadelli and Otfried Jarren (Wiesbaden: VS Verlag für Sozialwissenschaften, 2006): 341-61.

49. Herbert Simon, Behavioral Economics and Business Organization, (Cambridge: MIT Press, 1978), 456.

50. Nicholas Rescher, Complexity, 170.

51. Manfred Osten, Das geraubte Gedächtnis. Digitale Systeme und die Zerstörung der Erinnerungskultur (Frankfurt / Leipzig: Insel, 2004), 49.

52. Arthur Lupia and Mathew McCubbins, The Democratic Dilemma: Can Citizens Learn What They Need to Know? (London: Cambridge University Press, 1998).

53. Hans-Bernd Brosius, Alltagsrationalität in der Nachrichtenrezeption. Ein Modell zur Wahrnehmung und Verarbeitung (Opladen: VS Verlag für Sozialwissenschaften, 1995), 237.

54. Arthur Lupia and Mathew McCubbins, "The Institutional Foundations of Political Competence: How Citizens Learn What They Learn to Know," in Elements of Reason. Cognition, Choice, and the Bounds of Rationality, ed. Arthur Lupia, Mathew McCubbins and Samuel Popkin (London: Cambridge University Press, 2000): 47-66, at 47.

55. Samuel Popkin, The Reasoning Voter: Communication and Persuasion in Presidential Campaigns (Chicago: University of Chicago Press, 1991), 7.

56. Giovanni Sartori, The Theory of Democracy Revisited, (Chatham, NJ: Chatham House Press, 1987). 
wanes. The political competence that is required of each of us in a democracy can only be the result of an "interpretation of the whispers" ${ }^{17}$ in which we are submerged because of the diversity of competing interests and opinions.

Strategies for Simplification The difficulties of taking on the complexity of politics suggest we should be understanding of those forms of simplification to which we resort even though they do not represent more than a passing and insufficient solution. I propose, first of all, that we should not be overly severe with the "simplifying drift," 58 provided we keep sight of the fact that it is nothing more than that: the art of muddling through in the face of the difficulties presented by complex problems. This open-mindedness toward simplification does not imply a pragmatic justification for trying to escape from or reject complexity. It is not the exclusive patrimony of anyone, but the type of political maneuvering resorted to by almost everyone, both the self-confessed populists and those who believe they are no such thing. There are occasions when the decision to resort to what are called heuristic; procedureis a good solution, even if it is not ideal. This term refers to any approach to a problem by a method that, while not perfect, allows us to achieve a good deal of the solution we wanted.

We know today that human reasoning, the product of bounded rationality, can be characterized as selective search through large spaces of possibilities. The selectivity of the search, hence its feasibility, is obtained by applying rules of thumb, or heuristics, to determine what paths should be traced and what ones can be ignored. The search halts when a satisfactory solution has been found, almost always long before all alternatives have been examined. ${ }^{59}$

Through schematization or the recourse to stereotypes, we replace costly information with sufficient deliberation of the principal possibilities:

Heuristics are judgmental shortcuts, efficient ways to organize and simplify political choices, efficient in the double sense of requiring relatively little information to execute, yet yielding dependable answers even to complex problems of choice.

57. Dirk Baecker, Kommunikation (Leipzig: Reclam, 2005), 76.

58. Rupert Riedl, Strukturen der Komplexität: Eine Morphologie des Erkennens und Erklärens (Heidelberg: Springer, 2000), 340.

59. Herbert Simon, Massimo Egidi, Robin Marris and Riccardo Viale, Economics, Bounded Rationality and the Cognitive Revolution (Aldershot: Ashgate, 1992), 4. 
Insofar as they can be brought into play, people can be knowledgeable in their reasoning about political choices without necessarily possessing a large body of knowledge about politics. ${ }^{60}$

These are procedures that allow clarification, the naming of things and making even highly complex situations intelligible. Making use of these types of political simplifications means placing oneself into a revisable provisionality and resisting the fully consistent drive that would be a psychological stressor and would place us on a procedural path without end. In this way, it allows us, among other things, to overcome the possible paralysis of the decision. These procedures place us at a satisfactory but not ideal level of information, rationality, and intelligibility.

What type of simplification strategies am I discussing here? The primary one is moving the focus from the content toward those who decide, from the issues to symbols and staging, from the cognitive side of problems to their moral side. When things become complicated, the focus on people allows us to reduce complexity because it is easier to make a judgment about people than about the issues. ${ }^{61}$ Another great simplification that tends to accompany the personalization of issues is the moralization of problems. Knowledge is replaced by an assigning of guilt, indignation, or calls for personal exemplariness. Social criticism is resolved with a condemnation of people, and the challenge to dominant structures is set aside. The scandal that is limited to the behavior of the few depoliticizes judgments about the society in which we live.

We can bemoan the limitations imposed by the dominant framework, the search algorithms with their commercial interests, the authority of the gatekeepers, but in a complex society, they are all inevitable. We can and should subject them to a democratic review, but I do not believe it is possible to achieve popular political competence without some type of simplification. In any case, we should not lose sight of the fact that these heuristic judgments, as neurological research has repeatedly shown, are filled with biases, and they interpret the world in a conservative fashion, privileging available information: "the system tends to see what it expects to see." 62 This pragmatic selection favors established stereotypes and requires little cognitive

60. Paul Sniderman, Richard Brody and Philip Tetlock, Reasoning and Choice. Explorations in Political Psychology (London: Cambridge University Press, 1991), 19.

61. Hans Mathias Keplinger, Die Demontage der Politik in der Informationsgesellschaft (Freiburg: Alber, 1998), 180.

62. Daniel Kahneman, "Maps of Bounded Rationality: Psychology for Behavioral Economics," American Economic Review (December 2003): 1449-75, at 1454; and Niklas Luhmann, Zweckbegriff und Systemrationalität (Frankfurt: Suhrkamp, 1968), 23. 
effort. The recourse to classic ideological outlines diminishes our ability to articulate greater complexity and, therefore, it does not in the end resolve the problems that this occasions. These simplifications are useful and necessary, but they are not well suited for problems of great complexity.

Delegating to Experts Another possible solution to our political disorientation is delegation, representation, and the recourse to experts. Delegating has the effect of compensating for our lack of direct experience and the difficulty of building personal knowledge about many issues. When there is communication with cognitive asymmetry, it requires trust. ${ }^{63}$ Competent citizens acquire competence through being well informed, and they seek that information through witnesses, analysts, commentators, experts, etc. They compensate for their lack of knowledge by observing those observers, in other words, identifying and consulting with those they believe to be more competent than they are, ${ }^{64}$ whether it be people or organizations. It is often not so much blind faith in the authority of others as much as a procedure to confirm their prejudices, to build confidence in themselves: "people triangulate and validate their opinions in conversations with people they trust." ${ }^{\prime 65}$

In a complex and indirect second-hand world, we have no choice but to move onto a second-order complexity (recourse to professional observers) ${ }^{66}$ which means adhering to the reduction of complexity that others carry out. Gehlen spoke of a second-hand experience that intervenes as an intermediary between the limited realm of one's own experience and the un-navigable spaces of the social, political, and economic world. ${ }^{67}$

It is worth remembering that delegation is full of paradoxes. "The human being is an animal who wants to do everything by himself, but in order to do so, he has to delegate as much as possible-to then later bemoan that he can no longer do it all himself." ${ }^{68}$ Delegation is, by its very nature, not an irreversible procedure. It does

63. Hans Peter Peters, "Wissenschaftliche Experten in der öffentlichen Kommunikation über Technik, Unwelt und Risiken," in Öffentlichkeit, öffentliche Meinung, sociale Bewegungen," Kölner Zeitschrift für Soziologie und Sozialpsychologie 34 (1994): 162-90.

64. Alfred Schütz, "The Well-Informed Citizen: An Essay on the Social Distribution of Knowledge," in Collected Papers II: Studies in Social Theory (Den Haag: Nijhoff, 1946), 123.

65. Samuel Popkin, The Reasoning Voter: Communication and Persuasion in Presidential Campaigns (Chicago: University of Chicago Press, 1991), 7.

66. Niklas Luhmann, Die Gesellschaft der Gesellschaft (Frankfurt: Suhrkamp, 1997), 1098.

67. Arnold Gehlen, Die Seele im technischen Zeitalter: Sozialpsycologische Probleme in der industriellen Gesellschaft (Hamburg: Rowohlt, 1957), 49.

68. Hans Blumenberg, Beschreibung des Menschen (Berlin: Suhrkamp, 2006), 508. 
not definitively cancel one's own authority-which is what sustains democratic legitimacy - which is why it is always disappointing.

In the first place, it does not seem like the experts have so much authority when their opinions differ or fail to lead to incontestable knowledge. It is very difficult to trust blindly in expert scientific knowledge when there is a peculiar "cacophony of experts," ${ }^{69}$ and every report has the corresponding counter-report. ${ }^{70}$ With the spread of opinions, we have a democratizing factor but also a growing problem of credibility. It is not only that expert opinion competes in the public view with those who are not experts, but the experts themselves are in disagreement.

In fact, in technology and the natural sciences, there is a wide margin for interpretation, different schools or certain preferences, and less neutrality and disinterest than is assumed. Expert knowledge can be a "persuasive recourse" that is weaponized to impose certain interests. ${ }^{71}$ The recourse to expert knowledge does not always produce expected results; it does not necessarily provide more knowledge, more clarity and a better overview. In some ways, what the scientific system does is increase the complexity of the environment in which political systems act, producing more imponderability and contingency.

Therefore, not even the experts are free of perplexity, which was revealed by the discredit that befell economic science when it was incapable of interpreting the first alarms or understanding what had already come to pass at the beginning of the economic crisis. The idea of science and technology as neutral authorities is largely discredited, given that their innovations have effects that require certain political interventions, sometimes in the middle of scandals and catastrophes. While politics often turns to science for assistance, it is also not uncommon for politics to resolve scientific and technological errors.

"Democratic reason" is the epistemic superiority of the rule of the many rather than the few. The reasons against the aristocracy, the oligarchy, or the regime of experts are also cognitive. Even if it were possible to identify the most intelligent people and guarantee their virtue, a large number of moderately intelligent individuals with different ways of thinking have greater epistemic competence than

69. Nicholas Rescher, Complexity: A Philosophical Overview (New Brunswick: 1998), 185.

70. Armin Grunwald, "Zukunftstechnologien und Demokratie. Zur Rolle der Technikfolgenabsätzung für demokratische Technikgestaltung," in Technik und Demokratie. Zwischen Expertokratie, Parlament und Bürgerbeteiligung, ed. Kristen Mensch and Jan Schmidt (Opladen: VS Verlag für Sozialwissenschaften, 2003): 197-211, at 206.

71. Hans Peter Peters, "Wissenschaftliche Experten in der öffentlichen Kommunikation über Technik, Unwelt und Risiken," in Öffentlichkeit, öffentliche Meinung, sociale Bewegungen", Kölner Zeitschrift für Soziologie und Sozialpsychologie 34 (1994): 162-90, at 162. 
a mere handful of people who are very similar, no matter how intelligent they may be.

This does not mean that the many are infallible or that the social production of knowledge does not also have its dark side. There is no shortage of examples of collective stupidity. In point of fact, we should not overrate the possibilities of aggregation. There are topics about which the average citizen is not only ignorant but systematically mistaken. But this also applies to the experts (who have their own biases and characteristic errors, ${ }^{72}$ whose judgment must be introduced in the decisionmaking procedures, of course, but balanced with other democratic criteria. The intelligence of democracy is manifested precisely by successfully articulating knowledge, decision-making, and legitimacy.

Democracy cannot be rescued from public ignorance by virtue of some elites who are supposedly well informed and gifted with better criteria. Given the evidence of our public ignorance, it is not very likely for a democracy to be capable of selecting its experts without significant controversies (unless it is the experts who select their experts, which would, on the one hand, imply an endless regression and, on the other hand, would mean assuming unanimity between them). The selection of experts would require a clear idea about what expert knowledge consists of and how we can identify those "experts" who do not deserve to be labeled as such. This is a very problematic task that we sometimes have no choice but to carry out and that can always be disputed. ${ }^{73}$ Given that there is no such thing as "political expertise," improving knowledge does not entirely resolve our political problems. There would continue to be especially controversial political problems and social disagreement even if we were to exert as much effort as possible to achieve the knowledge of an issue's factual or technological dimension.

All of this has an unexpected democratizing effect: knowledge elites do not have a privileged perspective when it comes to what is socially unknown. ${ }^{74}$ In this way, ignorance has an equalizing effect; the lack of intelligibility is, in a matter of speaking, a force for democratization. Regarding certain particularly complex problems and general uncertainty, the elites are just as vulnerable as laypeople; the hope for elites who will resolve our problems is a true anachronism. Even the best informed and best educated citizen is overcome by the complexity of decisive problems.

72. Philip E. Tetlock, Expert Political Judgment: How Good Is It? How Can We Know? (Princeton, NJ: Princeton University Press, 2006).

73. Ian Shapiro, Democracy's Place (Ithaca, NY: Cornell University Press, 1996).

74. Ulrich Beck, Risikogesellschaft. Auf dem Weg in eine ander Moderne (Frankfurt: Suhrkamp, 1986), 274. 
In this way, we can conclude that, even though delegation and representation free us from having to concern ourselves with every topic and every detail, or to act with a degree of skill that we do not have. From the normative point of view, they do not absolve us of the function of observation and control. Representation and delegation only partially resolve the problem presented by the complexity of contemporary democracies since democracy_even in the minimalism that reduces it to a mere selection of leaders ${ }^{75}$ - presupposes the ability to assess the leaders' actions in the end. The political system in a democracy has no choice but to observe and critically control its advisors. Democracy reemerges as the solution to problems that it itself poses.

\section{Democratic Solutions to Make Politics Intelligible}

When democratic rights began to be universalized, those who were most conservative became concerned about the possible inability of the new citizens who were incorporated into the group of those who voice opinions and make decisions, in other words, those who are presumed to have full political judgment. John Stuart Mill $^{76}$ spoke of privileging the right to vote of the competent citizen (who was required to know how to speak, write, and count) and formulated a pedagogical responsibility for institutions to improve those abilities. Until the 1960s, there were "literacy tests" in some states in the US to allow voting (especially for blacks). ${ }^{77}$ This prejudice violates human rights and contradicts democratic principles, but I would like to call attention to a more fundamental error: the belief that political competence or incompetence is an individual matter.

The error of elitism is not so much that it underestimates people with less education but that it believes in political competence as a property of individuals and that the wisdom of political systems would be the result of the aggregation of individual properties. The value of democracy is not well understood when attention is fixed on the properties of the individuals who intervene in it (and neither is it correct to then propose better solutions). I am referring to all those conceptions of democracy that, in view of the complexity of decision making, understand democracy as a "peculiar aristocracy" 78 or those who celebrate (individual) cognitive

75. Joseph A. Schumpeter, Capitalism, Socialism, and Democracy (New York: Harper \& Brothers, 1942).

76. John Stuart Mill, Considerations on Representative Government, (London: Parker, 1861), 152.

77. Michael Schudson, The Good Citizen. A History of American Civil Life (New York: The Free Press, 1998), 182.

78. Russell Hardin, "Representing Ignorance," Social Philosophy and Policy 21 (2004), 7699 at 98. 
diversity and deliberation as the source of the best decisions. ${ }^{79}$ Both conceptions center excessively on individual properties and do not consider the institutional and procedural aspect of democracy. In my opinion, given that individual abilities are overburdened in the face of complexity and that individual ignorance is insurmountable, there is no solution other than strengthening the institutional and organizational components of collective intelligence.

Some people say that the Achilles of democracy is not the institutions or politicians but citizens. ${ }^{80}$ In my opinion, while our individual weaknesses are serious (whether found in those who govern or those who are governed, although each blames the other), the principal problem we must address is the inability of the political system when it comes to managing the world's growing complexity, making it politically intelligible. The lack of political competence is not an individual failure, which is why we should not expect too much out of the personal ability of voters nor is good politics determined by the those who represent us. Solutions need to be institutional and procedural; what must be improved is the ability of the political system to act intelligently-that is, collective learning. This collective learning includes, of course, the cognitive, emotional and moral abilities of individuals, without the global result being reducible to the improvement of individual properties.

When it comes to greater complexity, increasing the ability of citizens is not so much a question of strengthening individual abilities as improving those aspects of the social organization that enhance their cooperative abilities. In this case, the solution to the problem we are addressing would not be less democracy (recourse to experts, increasing the delegation of trust, or renouncing popular control) but more democracy, in the sense of a better interaction and a shared exercise of political faculties. ${ }^{81}$ Complexity would not then be an argument in favor of de-democratization but would act as an incentive to intensify the practices that allow us to fight uncertainty in a collective fashion.

79. Helene Landemore, Democratic Reason: Politics, Collective Intelligence, and the Rule of the Many (Princeton, NJ: Princeton University Press, 2013).

80. Jochen Detjen, "Von der Notwendigkeit kognitiver Anstrengungen beim Demokratielernen," in Demokratiekompetenz. Beiträge aus Politikwissenschaft, Pädagogik und politischer Bildung, ed. Gerhard Himmelmann and Dirk Lange (Wiesbaden: VS Verlag für Sozialwissenschaften): 28698, at 293.

81. Beth Noveck, Wiki Government: How Technology Can Make Government Better, Democracy Stronger, and Citizens More Powerful (Washington, DC: Brookings, 2019); Helene Landemore, Democratic Reason: Politics, Collective Intelligence, and the Rule of the Man (Princeton, NJ: Princeton University Press, 2013); and Geoff Mulgan, Big Mind: How Collective Intelligence Can Change Our World (Princeton, NJ: Princeton University Press, 2018). 
We must increase political competence, from the individual point of view through political education, ${ }^{82}$ but especially the collective abilities, through cooperation and intelligent systems of government. The reduction in complexity through individual education is insufficient. The individual is not capable of resolving the problem of unintelligibility alone. Politics is a social action, and its problems have nothing but collective solutions. The ability of which we are speaking is, in the end, a shared property. The production of knowledge and the acquisition of competence are fully realized in social contexts. Sociability compensates for individual shortcomings and allows us to put the processes of collective learning into motion; it can correct all those individual shortcomings that stem from our individual limitations of time, attention, and personal experience; it lets us elaborate information collectively, articulating the division of labor, and distributed intelligence. All the proposals for participatory or deliberative democracy are based on this assumption of understanding democracy as a "cooperative reflection," 83 where the identification and defense of one's own interests are carried out discursively in a common public space that is egalitarian and inclusive.

It would be a question of transforming hierarchies into ecosystems of collaborative knowledge and thus radically changing the culture of government from one of centralized expert knowledge to one in which social problems are addressed collectively. When there are issues that have to do with collective dynamics, the question that always arises is about whether the whole is greater than the sum of its parts, about whether there is not something supra-individual-the system, organized totality, an emerging phenomenon - that cannot be reduced to the intensions of the participating individuals. We talk about emergency precisely when there are general properties that cannot be reduced to the characteristics of their elements. A knowledge society is not a society in which there are more experts but one in which the systems are experts. It is not enough to have individuals learn and innovate; little is achieved if the citizens acquire new competencies while the rules, routines, and procedures (the organizational and public intelligence) prevent them from taking advantage of the new competencies. Changes are only realized when the structures, processes, and collective rules are also modified. The knowledge of a society is something more than the mere accumulation of existing knowledge, in the same

82. Derek Heater, Citizenship: The Civic Ideal in World History, Politics, and Education (London, New York: Longman, 1990), 336.

83. Axel Honneth, "Demokratie als reflexive Kooperation. John Dewey und die Demokratietheorie der Gegenwart," in Das Recht der Republik (Frankfurt: Suhrkamp, 1994): 37-65, at 41). 
way that an intelligent organization is intelligent because of the synergy that is produced in its systems of rules, institutions, and procedures, and not because of the mere addition of personal intelligences. The generation of knowledge is a consequence of communicative acts or, stated in another fashion, a relational good.

That fact that politics is a learning system does not mean that politicians are or should be very intelligent. As is the case with organizations, it is a question of a type of collective intelligence: the knowledge of the whole is not reduced to the knowledge of its members, even though the first is unthinkable without the second. There may have been wise politicians from whom the system has not benefited in terms of collective learning. There is only learning for the process if the inferences that individuals have carried out through their experience become incorporated in the memory and procedures of the organizations. The knowledge of an organization is not what is in the head of its members but in the systems of rules, culture of the organization, procedures, routines and processes, protocols for negotiation, decisionmaking, and the resolution of conflicts. Collective intelligence is a property that is emerging from social systems and that is not based on the mere aggregation of individual properties but on the intelligence belonging to the system itself. This is why it makes sense to talk about "governmental learning" or about an "intelligence of democracy." 84 The question is knowing if our political systems incorporate mechanisms to learn or if they are incapable of it because of their own configuration.

There are a lot of ways to strengthen society epistemically: increasing diversity, through the division of labor or promoting discussion and deliberation. I would mention the fact that the achievements of the scientific community form part of this collective intelligence, since it is also a genuinely collective activity, although not exempt from dissensions and rethinking. One particularly valuable proposal is the CrowdLaw to improve the quality of legislation: a concept originally proposed by Beth Noveck. ${ }^{85}$ It is based on the idea that parliaments, governments, and public institutions produce better legislation and public policies when they promote civic engagement, employ the technologies necessary at every moment, and make use of the available information and expert knowledge. A complex society requires more

84. Charles Lindblom, The Intelligence of Democracy: Decision Making through Mutual Adjustement (New York: Free Press, 1965).

85. Beth Noveck, et al., "CrowdLaw: Online Participation, Lawmaking GovLab White Paper," (2017), at https://crowd.law/table-of-contents-a34949e1ca24; and Victòria Alsina and José Luis Martí, "The Birth of the CrowdLaw Movement: Tech-Based Citizen Participation, Legitimacy and the Quality of Lawmaking," Analyse Kritik: Journal of Philosophy and Social Theory 40 (2018), 337-58. 
deliberate coordination, and projects like crowdsourcing, deliberative democracy, or open innovation point in this direction.

The complexity of modern societies does not necessarily condemn us to a loss of substance in democracy to the extent that it can be understood as an invitation to realize experiences of cooperative learning that benefit the actors as well as what we have in common. In this sense, we should say that it is not so much that democracy requires political competence as that political competence requires democracy; the acquisition of these properties, both cognitive and civic, is not fully realizable except in the context of an experience of common democratic life.

Daniel Innerarity is a professor of political philosophy, "Ikerbasque" researcher at the University of the Basque Country, director of the Instituto de Gobernanza Democrática, and part- time professor at the European University Institute (School of Transnational Governance). He is a former fellow of the Alexander von Humboldt Foundation at the University of Munich, visiting professor at the University of Paris 1-Sorbonne, and visiting fellow at the London School of Economics and at Georgetown University. His research focuses on the current transformations of the democratic government. His most recent publications include: Democracy in Europe (2018) and Politics in the Times of Indignation (2019). He can be reached at dinner@ikerbasque.org. 